\title{
一般座標系による河川分流を考慮した高潮・洪水同時生起の 数值シミュレーション
}

\author{
Numerical Study of Storm Surge - Flood Coupling by using the General Coordinate System
}

\author{
原 信彦 $^{1} \cdot$ 山田 正 $^{2} \cdot$ 柴木秀之 ${ }^{3}$
}

\author{
Nobuhiko HARA, Tadashi YAMADA and Hidenori SHIBAKI
}

\begin{abstract}
A surge-flood coupling model was developed for numerical analysis of the disaster phenomena in river and coastal areas. In the coastal area, the basic equations of storm surge model are the multi-level continuity and momentum equations integrated for each layer. The shear stresses and the pressure gradients are taken into consideration in the momentum equations. A general coordinate system is used due to its advantageous for the modeling the watercourse of complex shape of rivers. In the river areas, the basic equations of flood model are then two dimensional unsteady flow ones. The developed surge-flood coupling model is applied in this study for the analysis of the river current and the water level in the Tokyo Bay.
\end{abstract}

\section{1. はじめに}

日本は台風の常襲地域に位置し, 毎年いくつかの台風 が来襲するという厳しい自然環境下にある。そのため, 沿岸域は, 高潮災害により幾度となく甚大な被害を受け てきた. 日本の沿岸は人口, 資産など社会機能が集中し ている上に, $0 \mathrm{~m}$ 地帯があり, ひとたび浸水すれば, 広域 に渡り浸水が広がる可能性がある。資産が集中する地域 では農地など雨を地下に吸収する土地が少なく地表から 下水管に多くの雨が流れ达み, 結果として, 河川の水位 が短時間で上昇する。これにより, 高潮と河川水位のピ 一ク時間差が縮まり，両者の重畳の可能性が高まる。高 潮と洪水の同時生起の数值計算として, 村上ら（1984） は, 大阪湾奥部の淀川を対象とし, 海域を二次元単層の 非線形長波モデルとし, 河川域を一次元の不等流計算と し, 両者を接続させ, 実地形での計算を可能としている. しかし，河川域は矩形断面で仮定していることから，実 際の河川に沿った断面形状とすることや, 洪水流出の八 イドログラフなどを考慮することを今後の課題としてい る. 武田ら（1997）は, 大阪湾奥部の淀川を対象とし, 海域と河川にはそれぞれ, 非線形長波モデルと一次元不 定流計算を用い, 室戸台風コースで伊勢湾台風規模の計 画台風と流量ハイドログラフを与えて同時計算してい る. 高潮と洪水区間のすりつけ部と河口から $7.5 \mathrm{~km}$ 付近 で水位が堤防天端高に近づく可能性を示している。また, 柴木ら（2002）は，伊勢湾を対象に高潮推算の格子を用 いて，木曽三川をはじめとする河川からの淡水流入を八 イドログラフとして海域の高潮推算に与えている．河川

\begin{tabular}{llll}
\hline 1 & 正会員 & 工修 & 株式会社エコー防災・水工部 \\
2 & フェロー & 工博 & 中央大学教授理工学部土木工学科 \\
3 & 正会員 & 博 $($ 工) & 株式会社エコー防災・水工部
\end{tabular}

流を考慮すると, 伊勢湾西岸で約 $5 \mathrm{~cm}$ 潮位偏差が上昇す るとしている.ただし, 高潮推算の計算格子で河川流量 を与えていることから, 河口部付近を河川流上流端とし ている. 本研究では, 実河川の複雑な地形を表現するた めに, 二次元不定流モデルを採用する. デカルト座標系 の高潮推算モデルで河川流を考慮する場合, 海域の計算 格子間隔では河川の地形近似精度は低下し, 河川幅に合 わせると格子数が膨大となり, 効率的な計算が難しい. そこで, 実河川の複雑な地形を表現し, かつ非計算格子 数がデカルト座標系に比べ少ない一般座標系による二次 元不定流モデルとする. そして, 海域格子と河川要素を 結合し, 高潮と洪水の数值計算を同時に行うモデルを開 発する。対象領域は，東京湾奥部の江戸川と旧江戸川の 河口とし, 河川分流を考慮した地形による高潮と洪水同 時生起の状況を予測し, 結合型モデルの有効性および, 河川流と潮位偏差の発生特性を分析する。

\section{2. 数値計算モデル}

\section{（1）高潮推算モデル}

海域で用いる高潮推算モデルは，層別に鉛直積分した 多層非線形長波モデルを使用し, 気圧の低下と海上風の 吹き寄せによる効果を考慮する，ただし，本論文では， 河川で使用する二次元不定流計算が, 単層であることか ら, 高潮推算に関しても, 多層モデルを単層として推算 を実施する。離散化は, 非線形項に風上差分を用い, 空 間差分にはスタッガード格子とし，時間差分にはリー プ・フロッグ法を用いる. なお, モデルの詳細は, 柴木 ら（2002）を参照されたい.

\section{(2) 二次元不定流計算}

河川域に用いる計算は, 実河川など複雑な形状の表現 能力が高く, 比較的容易に計算格子を形成することがで 


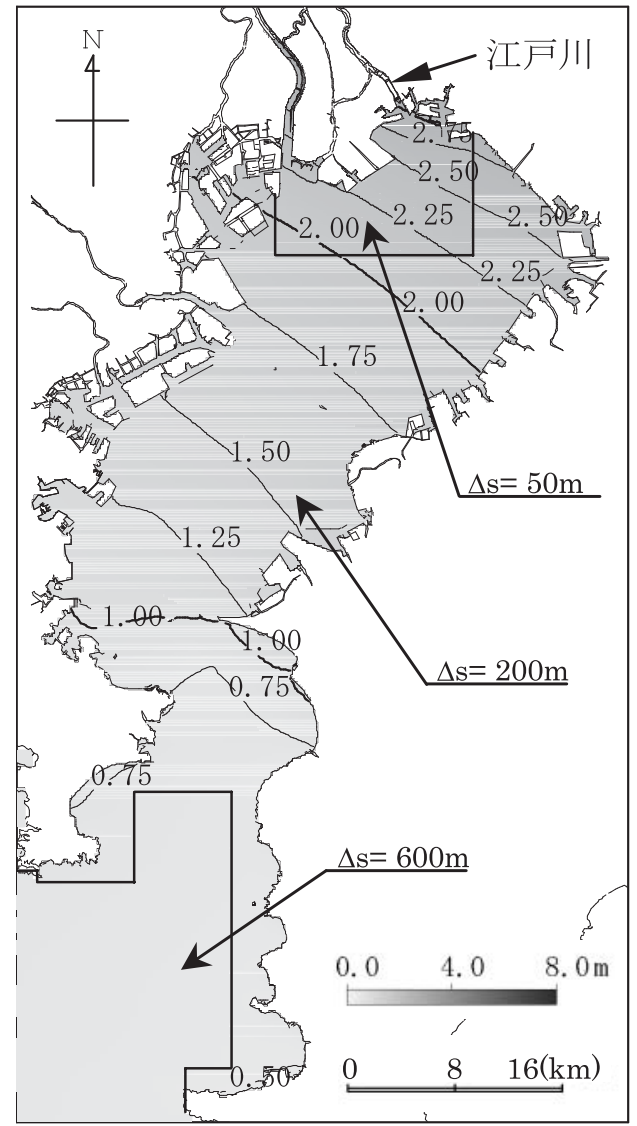

図-1 Case 1における東京湾内の最大水位分布

きる一般座標系による二次元不定流計算を用いる。なお， 計算モデルは，水理公式集例題プログラム集（2001）に 収められているものを使用する。一般座標系の基礎式は, デカルト座標系の二次元不定流計算式を，ヤコビアンを 用いて座標変換したものである. 数值解析法は, 有限体 積法とし，離散化は，非線形項に風上差分を用い，空間 差分にはスタッガード格子とし，時間積分にはAdamsBashforth法を用いる。なお，モデルの詳細は，水理公式 集例題プログラム集（2001）を参照されたい.

\section{（3）高潮推算と二次元不定流計算の同時計算}

海域と河川の結合は，両者の連続式を満足するように， 河川下流端要素から算出された流量を海域の河口部格子 に与える。ここで，海域格子と河川要素の数は一致しな いため, 河川の各要素から得られる流量を海域格子に分 配し流入させる。一方, 海域からは，河川部要素に水位 を与え，河川の下流端条件とする，河川下流端水位は， 海域格子の近傍の水位とする.

海域と河川域の同時計算に際して，高潮推算と二次元 不定流計算の計算時間間隔は，それぞれ，2.0s，0.2sであ る。したがって，高潮推算を 1 ステップ計算後，二次元

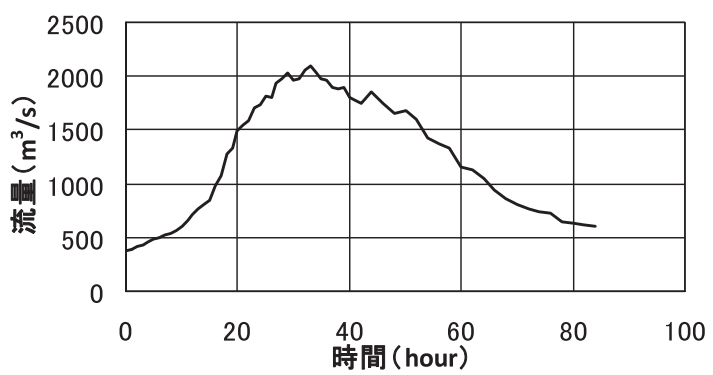

図-2＼cjkstart高潮・洪水流量ハイドログラフ

不定流計算を 10 ステップ計算する.

\section{3. 数値計算条件}

高潮推算に用いる台風は, 東京湾の海岸保全基本計画 策定時に適用した想定台風とする。想定台風に関して, 増田ら（2003）によると，東京湾内に大きな影響を及ぼ すと考元られる台風7920号, キティ台風, 伊勢湾台風の 3タイプのコースを設定し，これらの想定コースを $0.2^{\circ}$ 刻 从で東西方向に平行移動させ, 東京湾内の各地区で危険 となるコースを選定している，台風の規模に関しては， 中心深度を $70 \mathrm{hPa}$, 台風半径を $75 \mathrm{~km}$, 移動速度を $73 \mathrm{~km} / \mathrm{h}$ とした伊勢湾台風級としている。これょり，江戸川河口 部に最も危険となるコースは, 上陸時の緯度・経度が北 緯 $34.5^{\circ}$ ，東経 $139.0^{\circ}$ の伊勢湾台風コースとなる，想定 台風の期間は 9 月 25 日 9 時〜 27 日 3 時である。また，本 論文では，想定台風の中心深度を $1 / 2$ とした，台風規模 の小さい条件の計算も実施する.

図-1 は後述するCase 1 の最大水位平面分布である。東 京湾内の領域構成は，図-1に示すように，想定台風の経 路を含む広域とし，東京湾内を $200 \mathrm{~m}$ 格子，江戸川河口 部周辺を $50 \mathrm{~m}$ 格子で地形近似する。 また，東京湾内の最 大水位から，東京湾湾口では， $0.7 \mathrm{~m}$ 程度となり，湾奥ほ ど水位が高い. 江戸川河口部は, 湾内で最も水位が高く, $3 \mathrm{~m}$ 程度となる。

江戸川の上流端境界は, 河口から約 $40 \mathrm{~km}$ の野田の水 位流量観測地点とし，河川流量は，福岡（2005）に示さ れている 2001 年 9 月 11 日の洪水流量ハイドログラフと $200 \mathrm{~m}^{3} / \mathrm{s}$ 一定の流量を与える。河川の地形デー夕は, 複断 面水路とし，江戸川と旧江戸川の分流を表現する，河川 の要素配置は，後載する図-8に示すように，分流付近に おいて，両河川とも流下方向に滑らかな要素配置とする. また，図-2に示す，洪水流量ハイドログラフを用いる予 測ケースについては, 河川流量と潮位偏差のピークを江 戸川河口部で一致させる．表-1に予測計算ケース一覧を 示す。ここで，江戸川河口の行徳可動堰に関しては全ケ ースとも引き上げたままの条件とする. 
表-1 予測計算ケース一覧

\begin{tabular}{c|c|c}
\hline Case No. & 河川流量 & 台 風 \\
\hline Case 1 & $200 \mathrm{~m}^{3} / \mathrm{s}$ 一定 & 想定台風 (中心深度: $70 \mathrm{hPa}$ ) \\
\hline Case 2 & 最大 $2,100 \mathrm{~m}^{3} / \mathrm{s}$ & な \\
\hline Case 3 & 最大 $2,100 \mathrm{~m}^{3} / \mathrm{s}$ & 想定台風 (中心深度: $70 \mathrm{hPa}$ ) \\
\hline Case 4 & 最大 $2,100 \mathrm{~m}^{3} / \mathrm{s}$ & 想定台風（中心深度: $35 \mathrm{hPa}$ ) \\
\hline
\end{tabular}

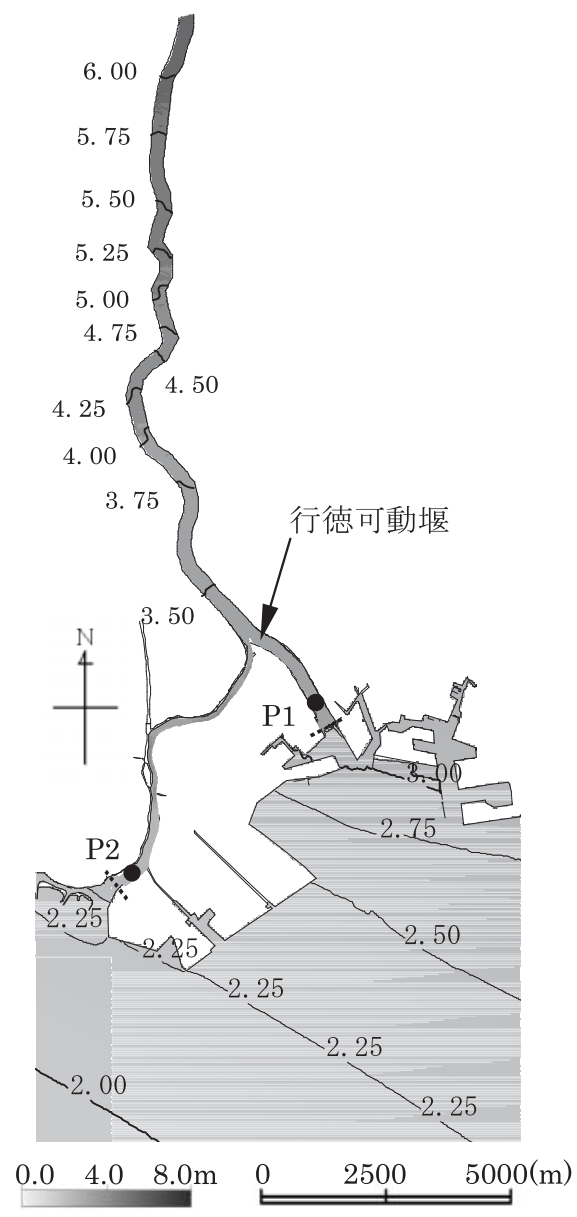

図-3 Case 3 の最大水位平面分布

\section{4. 高潮・洪水同時計算結果の分析}

\section{（1）河口部の最大水位と水位，流量変動}

図-3は, Case 3 の海域および河川域の最大水位平面分 布であり, 河口部の破線は, 河川と海域の計算接続境界 である．海域から河川上流に向け徐々に水位が高くなり, 江戸川および旧江戸川河口付近の最大水位はそれぞれ $3 \mathrm{~m}, 2.5 \mathrm{~m}$ 程度となり, 分流付近では, $3.3 \mathrm{~m}$ 程度となる. 想定台風による最大水位は, 江戸川河口部の方が，旧江 戸川よりも高くなる. 海域と河川域の接続部分の水位に 不連続な個所は見られない. また, 流速に関しても同様 であり，数值計算上の接続は妥当であると確認できる.

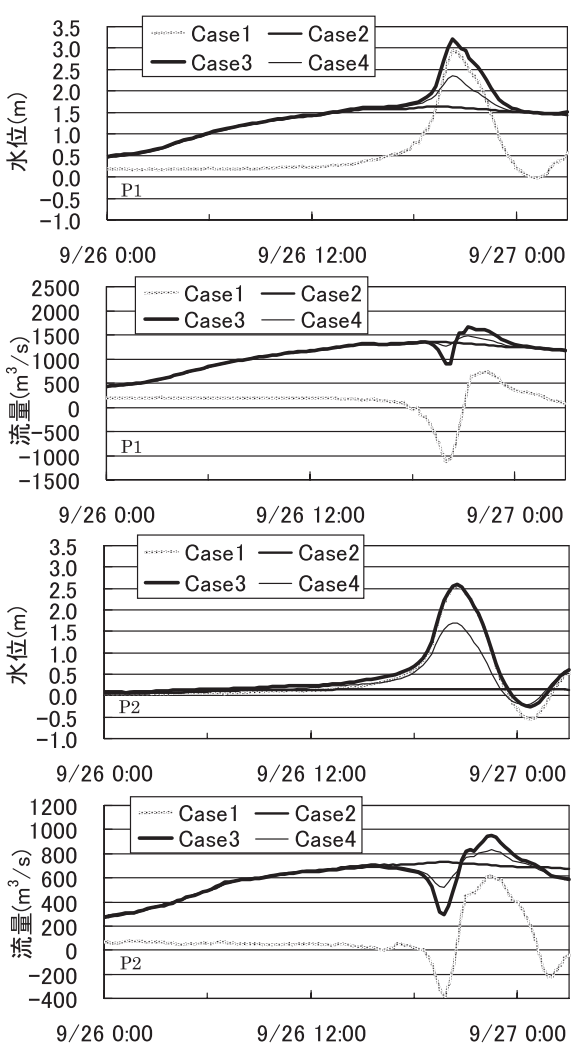

図-4 各ケースにおける河口部の水位と流量 (上：P1, 下：P2)

図-4は，図-3に示している2箇所（P1（江戸川)，P2 (旧江戸川)）の河口部の水位および流量の時系列である. 想定台風による江戸川と旧江戸川河口部での最大潮位偏 差は, 河川流量にかかわらず，それぞれ $3 \mathrm{~m}, 2.5 \mathrm{~m}$ 程度 となり, 台風規模の小さいCase 4 では, $2.4 \mathrm{~m}, 1.7 \mathrm{~m}$ 程度 となる。そして, 河川流量が多く台風規模が大きいCase 3 の水位が最も高い. 河川流量の異なる Case 1 と Case 3 の 水位時系列から台風通過後の摇れ戻しに差が見られ, 河 川流量の多いCase 3 の摇れ戻しが小さい. Case 1では, 高潮による水位上昇から, 河川流量が負となり, 河口か ら海水が遡上している. Case 2, Case 3, Case 4は, 台風 規模の異なる条件であり, 台風接近までは, 洪水流のみ の影響で水位と流量はほぼ同じ変動を示す。台風が来襲 すると, 規模の大きい台風ほど水位が上昇し, 流下する 流量は少なくなる.

\section{（2）海域河口の水位と流速分布}

図-5は,Case 1 とCase 3 の江戸川河口部付近の最大水 位の差図である。海域では $0.02 \mathrm{~m}$ 以下の差であるが, 河 口部付近で $0.1 \mathrm{~m}$ 程度の水位差が生じ, 河川流量の多い Case 3 の方が高い. 図-6は, 洪水流のみのCase 2の江戸 川河口部付近の最大水位平面分布である. 洪水による水 
位上昇は, 図-5の水位差の分布と近く, 洪水流により河 口付近で水位は $0.2 \mathrm{~m}$ 程度上昇するが, 海域は $0.02 \mathrm{~m}$ 以下 の水位上昇となる。図-7は, Case 1, Case 2, Case 3の台 風接近時刻の江戸川河口部の流速ベクトルである. Case 1 は, 河川流量が少ないことから, 高潮による吹き寄せ の影響により，流向は江戸川河口方向に卓越する. Case 2 は, 洪水流のみであることから, 河川から海域へ放射 状に流れている. 河口部付近で速い流れとなるが, 海域 ではほとんど流速がなく, 図-6の水位分布と一致する. Case 3 は，高潮と洪水の影響を受けているケースである. Case 1 に比べ高潮による河口への流速が遅く, Case 2 に 比べ河川からの流出流速も遅くなる. Case 3 は, Case 1 と Case 2 の流速を合成したような流速べクトル分布とな る.よって, 河口部では, 河川側と海側の両者の影響を 受けることから，河口部付近で強制的に水位制御などを 行うと, 水位および流速は誤って予測される可能性があ る. 本論文の高潮・洪水同時計算は海域と河川域を結合 していることから，上述の問題を回避できる.

\section{（3）河川分流箇所の流速}

図-8は，河川分流周辺のCase 1の流速ベクトル図であ る. 図中の灰色部は高水敷である. 台風来襲時（上図） は, 河口までほぼ直線的で河川幅が広く, 分流地点から 河口までの河道距離が短い江戸川河口から高潮が遡上す る. 河川分流付近の上流右岸側では，渦流が発生してい る。渦流は，旧江戸川へ流れ込む形となり，旧江戸川か らの高潮の遡上を阻害している。これは，図-4の 2 つの 河川河口部の時系列において, 潮位偏差に $0.5 \mathrm{~m}$ 程度の差 があることや, 河川幅や河口までの距離, 蛇行などの河 川形状が河川内の流速を支配していると考えられる. 台 風通過後（下図）は, 江戸川河口から遡上した水塊が海 域に戻る。水塊は流入した江戸川だけでなく，旧江戸川

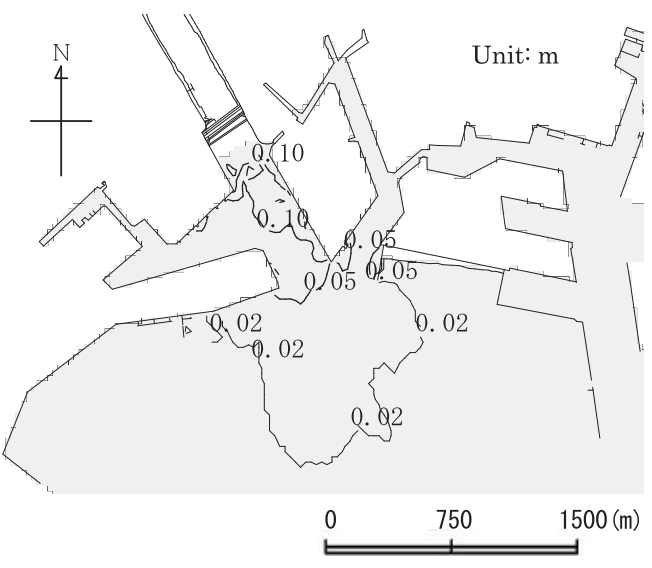

図-5 Case 1 とCase 3 の河口部付近の最大水位差図 (正ならばCase 3 の方が高い)

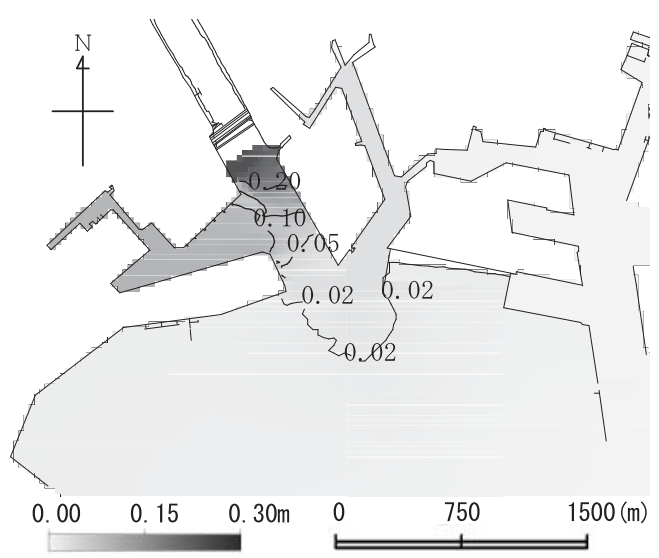

図-6 Case 2 の最大水位平面分布

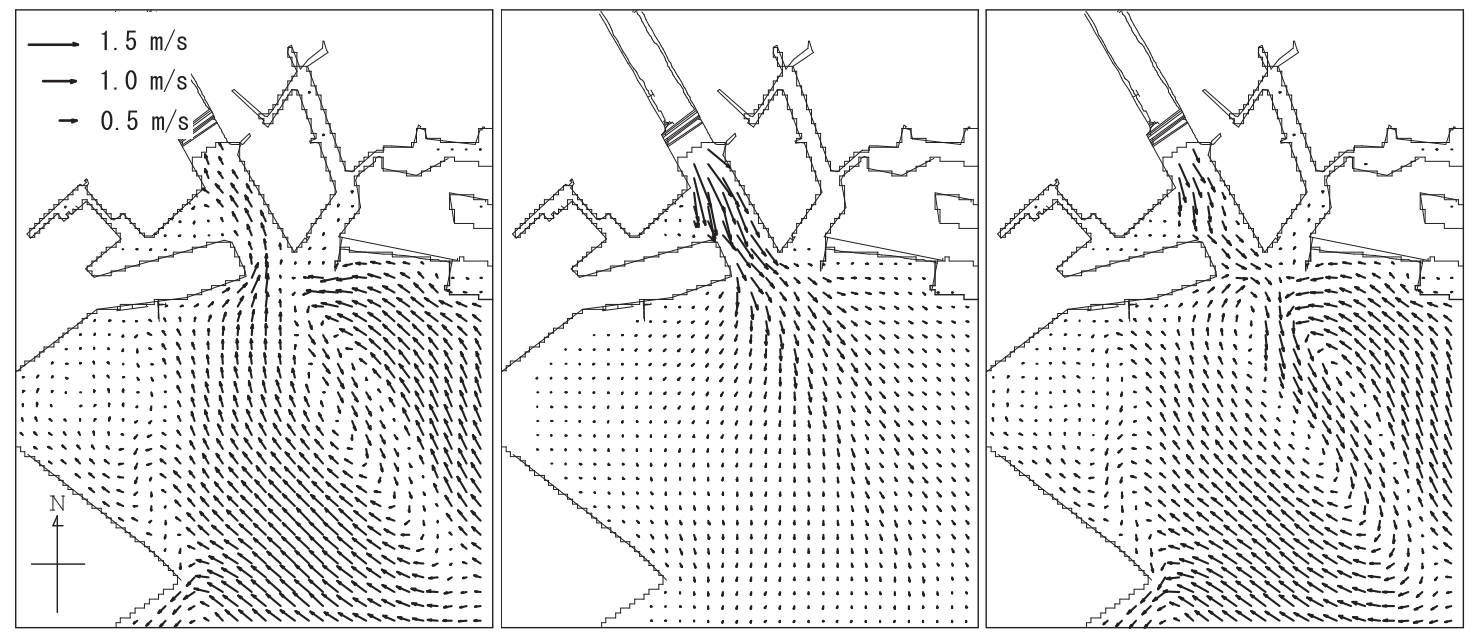

図-7 河口部の流速ベクトル図（26日 19：00，左：Case 1, 中：Case 2, 右：Case 3) 


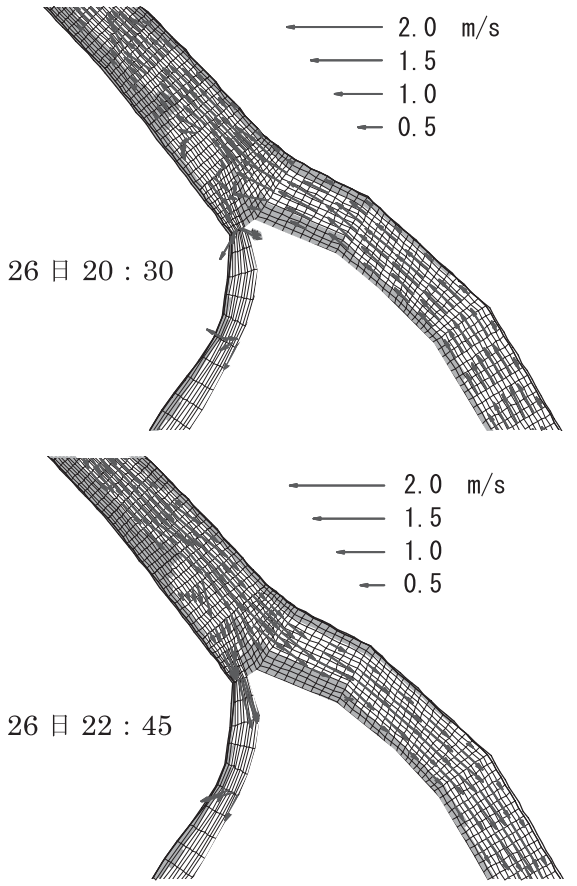

図-8＼cjkstart河川分流付近の流速ベクトル図（Case 1)

へも流れる.また，両時刻ともに，高水敷の流速は遅く， 低水敷に流れが集中する状況が予測される.

\section{（4）河川分流河道内の縦断水位}

図-9は, 河川計算下流境界から約 $23 \mathrm{~km}$ 上流の最大水 位で除して無次元化した江戸川における河川縦断方向の 最大水位である. Case 1 の場合，他のケースに比べ河川 流量が少ないことから，より上流まで高潮の影響を受け る. 高潮による河川内の水位は, 無次元化した值で 0.7 〜 0.9 倍程度であり, 高潮が影響する区間の水位はほほ 一定となる. Case 2〜 4の場合, 洪水流の影響により, 高潮の河川遡上距離は短くなる。 また, 台風規模が大き いほど下流側の水位が高いため，より上流まで高潮の影 響を受ける. Case 2 と Case 3，Case 4を比べると，それぞ れ上流端から $11.5 \mathrm{~km}, 15.3 \mathrm{~km}$ 付近で差が生じ, この地点 まで高潮が影響する，高潮の影響は，河口での水位よりも 高い位置まで見られ, 遡上による水位上昇が確認できた.

\section{5. おわりに}

東京湾奥部の江戸川河口を対象とし，河川分流を考慮 した地形により，一般座標系による二次元不定流計算と， 非線形長波モデルによる高潮推算の結合型モデルを開発 した。そして，高潮と洪水同時生起の状況を予測し，結 合型モデルの有効性および, 河川流と潮位偏差の発生特 性を分析した.

以下に成果をまとめる.

(1) 海域のデカルト座標系と河川域の一般座標系の接続

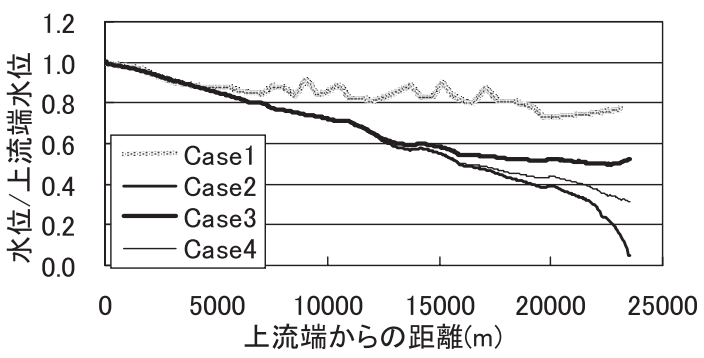

図-9 河道内の最大水位

(河口から約 $23 \mathrm{~km}$ 上流地点で無次元化)

は，両者の連続式を満たすように設定することにより， 効率的かつ合理的な高潮・洪水の同時計算を実施する ことができた、

(2) 河川域を一般座標系による二次元不定流モデルを採 用することにより，複数の分流や複断面水路の河川地 形にも柔軟な適用が可能となった。

(3) 4ケースの予測計算を実施し，河川流の影響を分析 した．河川流により台風通過後の摇れ戻しが小さくな る. 河口部では $0.1 \mathrm{~m}$ 程度水位が高くなり, 河口部付近 で強制的に水位を制御すると水位，流速を誤って予測 する可能性があることがわかった。

(4) 河川分流を分析すると, 高潮は江戸川河口部のみか ら遡上し, 台風通過後は, 両方の河川から流出する. 流れは，低水敷に集中することが確認できた。

(5) 高潮の影響は, 河口部の潮位より高い地点まで見ら れ，遡上による水位上昇が確認できた.

(6) (3)〜 (5)で述べたように, 高潮・洪水結合型モデルに より，高潮と洪水の重畳に伴う多様な水理現象を表現 することができるようになった。

今後の研究は, 高潮と洪水の結合モデルを用い, 高潮 と洪水による浸水が重なる計算の実施を予定している.

\section{参 考 文 献}

柴木秀之・渡辺 晃 (2002) : 密度成層とWave Setupを考虑 した多層高潮推算に関する研究, 土木学会論文集, No.719/ II -61, pp. 47-66.

武田 誠・平山克也・井上和也 - 戸田圭一（1997）：高潮と 洪水の重畳災害に関する基碟的研究，第 44 回海岸工学論 文集, pp. 351-355.

土木学会水理委員会水理公式集改訂小委員会水理公式集例題 プログラム集編集部会（2001）：水理公式集 例題プログ ラム集（平成 13 年版), $39 \mathrm{p}$.

村上和男・森川雅行（1984）：河川遡上を考虑した高潮の数 值計算, 第31回海岸工学講演会論文集, pp. 213-217.

福岡捷二（2005）：洪水の水理と河道の設計法, 森北出版株 式会社, $660 \mathrm{p}$.

増田勝人 - 柴木秀之 - 仲井圭二 ・ 鈴山勝之 (2003) : 東京湾 海岸の想定高潮偏差と新たな計画偏差について, 海洋開 発論文集，第19卷，pp. 689-694. 